\title{
CT-scanning of the drying process of Eucalyptus nitens
}

\section{Couceiro, J. ${ }^{\text {a*}}$; Hansson, L. ${ }^{\text {b; }}$ Ahec, A. ${ }^{\text {; }}$ Sandberb, D. ${ }^{\text {a }}$}

${ }^{a}$ Department of Engineering Sciences and Mathematics. Division of Wood Science and Enginering. Luleå University of Technology (LTU), Skellefteå, Sweden.

b Department of Ocean Operations and Civil Engineering. Norwegian University of Science and Technology (NTNU), Ålesund, Norway.

c Department of Wood Science and Technology. University of Ljubljana Biotechnical Faculty, Ljubljana, Slovenia.

*E-mail of the corresponding author: jose.couceiro@ltu.se

\begin{abstract}
The drying of Eucalyptus nitens is a troublesome process as the species is extremely prone to drying defects. This paper reports ongoing research to improve the understanding of surface checking and cell collapse in Chilean grown Eucalyptus nitens during drying. Computed tomography (CT) scanning was used as a powerful tool for studying the internal changes in the wood-material during the drying process. Different levels of temperatures have been tested with the same equilibrium moisture content (EMC) conditions and low air velocity. The results confirm that a low drying temperature and a low air velocity, which results in a slow rate of drying, reduce internal cell collapse and surface checking .
\end{abstract}

Keywords: Cell collapse; computed tomography; surface checks; wood drying; internal checks 


\section{Introduction}

Eucalyptus is the largest single source of market pulp in the world [1] . In Chile, 35\% of the forest plantations are eucalyptus (mainly Eucalyptus globulus and Eucalyptus nitens) [2]. The production of eucalyptus wood in Chile has been increasing during the last 40 years, but the volume of eucalyptus used as sawn timber has nevertheless decreased during that period.

The desire to increase the use of eucalyptus and to improve its processing has driven research in various fields. Blackburn [3] provides a wide picture of the existing knowledge of eucalyptus wood from different points of view: materials science, genetics, forest management and commercialized products. More recently, Sharma et al. [4] studied a new method to improve the quality of Eucalyptus nitens and Eucalyptus bosistoana solid wood by eliminating growth stresses. Kong et al. [5] investigated the use of steaming as pretreatment for Eucalyptus grandis and Eucalyptus urophylla wood and identified potential ways to improve the drying process.

One of the reasons for the low use of eucalyptus in solid wood products is the difficulties in the drying process, which usually result in an unacceptable level of defects, often due to cell collapse [6-8]. Cell collapse is a process that occurs mainly when there is free water in the wood cells and thin-walled cells cannot withstand the tension forces generated when the liquid water is displaced [9]. The literature reports research that addresses surface and internal checking and cell collapse of different eucalyptus species from various viewpoints, e.g. anatomical [10-12], materials science [6, 13-14] and genetics [15-16].

The topic of collapse in wood drying has been studied extensively. Recently, Yang and Liu [9] provided an extensive review of the literature on the collapse behaviour of different eucalyptus species and, based on these reports, proposed different measures to reduce it, such as pre-heating (both with steam and with microwaves), re-conditioning and several methods to control the drying parameters.

Different scanning technologies have been applied to study the cell collapse: WentzelVietheer et al. [17] tried to identify collapse zones in Eucalyptus globulus with near infrared spectroscopy (NIR). Ananías et al. [18] used a Quintek Xray Ring Tree Analyzer to measure the width and density of annual rings while studying how the location of the cell within the stem influences collapse.

The work presented in this article is a part of a larger project where the drying of Eucalyptus nitens is studied. To study internal cell collapse, an unique equipment that combines a drying chamber and a medical computed tomography (CT) scanner is used in such a way that the wood specimens can be scanned during drying in controlled conditions. 
It is then possible to explore what happens in the interior of a wood piece during the drying process and also to study the changes in dimension and density.

\section{Materials and Methods}

Eucalyptus nitens was harvested from Chilean plantations, sawn and shipped in the green state to northern Sweden, where the experiments took place. The specimens were sawn in dimensions of $47 \times 162 \times 600 \mathrm{~mm}$ and $27 \times 162 \times 600 \mathrm{~mm}$ with different orientations in the log cross-section (Fig. 1). Prior to drying, the cross-sections of the specimens were sealed with a heat-resistant silicone.

A specially designed laboratory drying kiln that fits within the void of a Siemens Somatom Emotion Duo medical CT-scanner was used (Fig. 2). With this equipment, it is possible to scan the inside of the kiln without interrupting the drying process, and thus to inspect in real time internal features of the wood specimens as they are drying. The control parameters are the air velocity and the dry and wet bulb temperature $\left(T_{d}\right.$ and $\left.T_{w}\right)$.
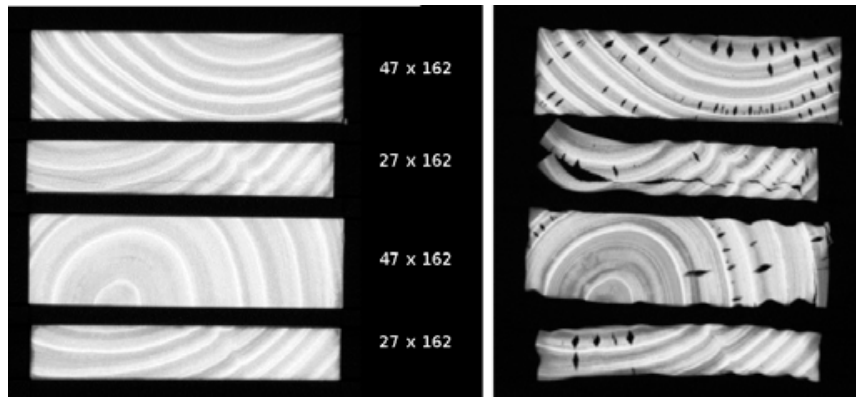

Fig. 1: CT-images of the cross section of the specimens before (Left) and after drying - experiment No. 4 in Table 1 (Right).

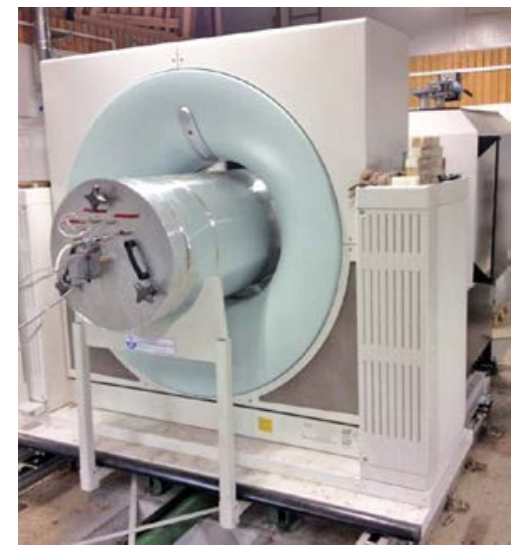

Fig. 2: Drying kiln and CT-scanner. The specimen is located in the metal tube that fits within the gantry of the scanner. 


\subsection{Drying processes}

The part of the project presented here consisted of slow drying under stable conditions. The aim was to maintain a constant air velocity just below $1 \mathrm{~m} / \mathrm{s}$, and conditions for the same equilibrium moisture content (EMC) 16\% (modifying the psychrometric difference in each run) and under these conditions to apply different drying schedules at four different temperatures, with four samples in each run in the chamber (Table 1). This was not always possible, as such a low air velocity made it difficult for the control system to hold the climate because the humidity in the chamber is controlled by the psychrometric difference, which requires a higher air velocity. Fig. 3 shows the actual temperature and humidity trends in each experiment, showing the difficulties of reproducing such schedules in some cases (compared with the set points shown in Table 1) and the consequences of several malfunctions of the equipment that had to be dealt with while the tests were running.

Table 1: Temperatures set points for each experiment.

\begin{tabular}{lll}
\hline Experiment No. & Dry-bulb T $\left({ }^{\circ} \mathrm{C}\right)$ & Wet-bulb T $\left({ }^{\circ} \mathrm{C}\right)$ \\
\hline 1 & 90 & 87.9 \\
2 & 60 & 57.3 \\
3 & 25 & 22.5 \\
4 & 40 & 36.9 \\
\hline
\end{tabular}
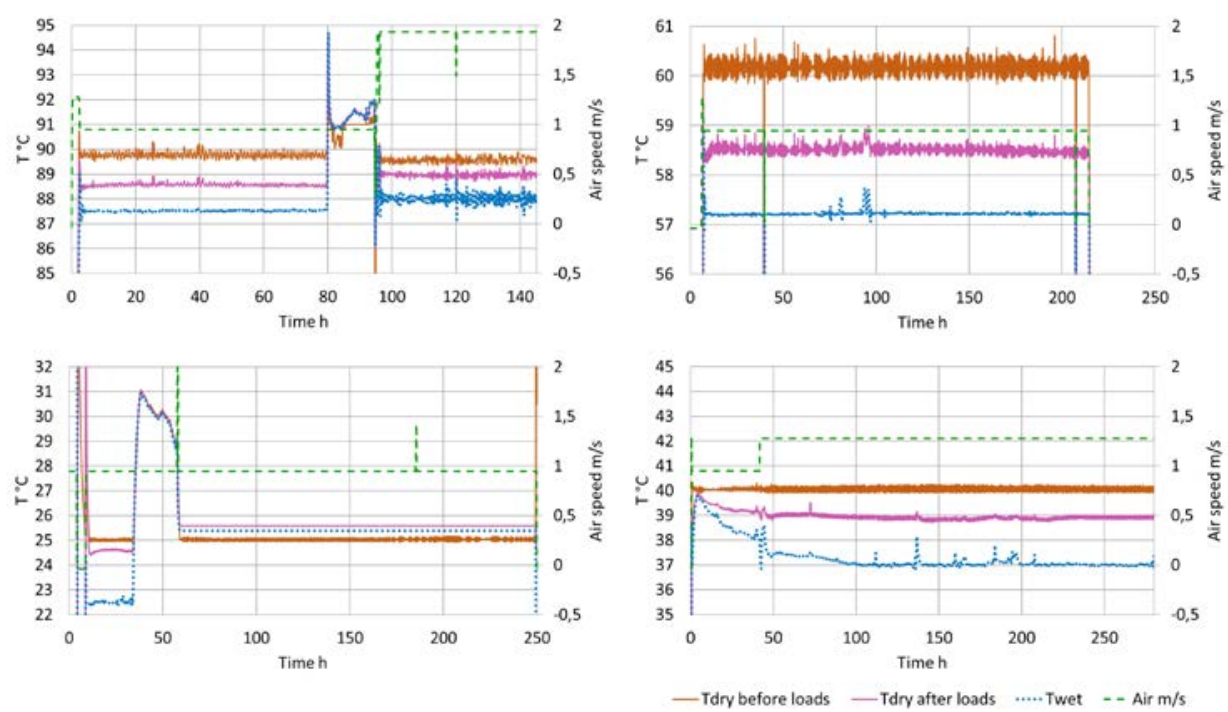

Fig. 3: Actual temperature and air velocity trends in the four experiments using the set points indicated in Table 1: 1 (top left), 2 (top right), 3 (bottom left) and 4 (bottom right). 


\subsubsection{Experimental issues}

Several issues arose during the experiment that made it necessary to change some of the parameters so that the drying kiln would continue running. During experiment No. 1 , the steam valve broke and it could not be replaced with the chamber in operation. To keep the experiment running and the EMC at a reasonable level, the air velocity was increased to around $1.9 \mathrm{~m} / \mathrm{s}$. The chamber also experienced malfunction early on during experiment No. 3 , and the data for wet-bulb temperature $\left(\mathrm{T}_{\mathrm{w}}\right)$ and dry-bulb temperature $\left(\mathrm{T}_{\mathrm{d}}\right)$ after loads are not reliable after about 60 h. Experiments No. 2 and No. 4 ran reasonably well. During experiment No. 4, the chamber had problems in reaching the working conditions for the test, and the air velocity was therefore incremented after around $40 \mathrm{~h}$.

\subsection{Data processing}

The data obtained from the CT-scanner are images in DICOM format, which translate into grey-scale images in which a lighter colour represents a high density and a darker colour represents a low density (Fig. 1). Each pixel of the image represents a volumetric entity (so called voxel) defined by the pixel size and the thickness of the scanning beam. In these experiments the voxel size was $0.49 \times 0.49 \times 10 \mathrm{~mm}^{3}$. Being a grey-scale image, each pixel has one numeric value associated with it (the CT-number), and the images can thus be processed as matrixes in mathematical software like, for example, Matlab, and this is the case with the data here presented. Making use of the density relationship between the CTnumber and the density of the scanned material, mass can be inferred and, thus, real time studies of moisture content (MC), defined as the ratio of the weight of the water in the wood to the dry weight of the wood, can be made.

The MC is calculated from the CT-images by dividing the difference between the average mass of the wood pixels in the wet wood image and the average mass of the wood pixels in the dry wood image by the average mass of the wood pixels in the dry wood image. This method is somehow analogous to the gravimetric method, which consist on dividing the difference in weight of a wood specimen at a given MC and in totally dry condition by the weight of the wood specimen in totally dry condition.

\section{Results and Discussion}

Two main aspects were studied: the drying rate and the evolution of internal cell collapse and surface checking.

\section{1. Drying rate}

As shown in Table 2, the lowest temperature gave the best drying rate, which is a confirmation of the validity of the traditional drying schedules used in Chile, which are performed at around $28^{\circ} \mathrm{C}$ with very low air velocity. A dry shell can be seen in experiment No. $3\left(25^{\circ} \mathrm{C} \mathrm{T}_{\mathrm{d}}\right)$, and to a shorter extent in experiment No. $4\left(40^{\circ} \mathrm{C} \mathrm{T}_{\mathrm{d}}\right)$, but not in the 
experiments at higher temperatures. Nevertheless, the results show that the drying rate is almost as high at $90^{\circ} \mathrm{C}$ as it is at $25^{\circ} \mathrm{C}$, which was one the hypothesis. Unfortunately, there is a high spread on the results, which suggest that conclusions should be drawn carefully.

Table 2: The drying rate of the different specimens sorted by dimension.

\begin{tabular}{lllllll}
\hline Experiment No. & Temp. $^{\circ} \mathrm{C}$ & 27 x 162 & 27 x 162 & 47 x 162 & 47 x 162 & Mean \\
\hline 1 & 90 & -0.45 & -0.19 & -0.25 & -0.30 & -0.30 \\
2 & 60 & -0.30 & -0.18 & -0.15 & -0.16 & -0.20 \\
3 & 25 & -0.39 & -0.37 & -0.27 & -0.29 & -0.33 \\
4 & 40 & -0.26 & -0.25 & -0.25 & -0.19 & -0.24 \\
\hline
\end{tabular}

\subsection{Cell collapse and surface checking}

Table 3 shows how the checking and cell collapse varied in each experiment. Fig. 1 shows, as an example, the checking and collapse occurring during experiment No. 4. If time were the only parameter to evaluate, experiment No. 4 (at $40^{\circ} \mathrm{C} \mathrm{T}_{\mathrm{d}}$ ) could be considered to show the best behaviour regarding the appearance of surface checks, while the CT-images showed that collapse took place more slowly in experiment No. 3 (at $25^{\circ} \mathrm{C} \mathrm{T}_{\mathrm{d}}$ ).

Table 3: Visibility of the first checks (surface) and cell collapse (internal checks) shown in hours into the drying process.

\begin{tabular}{lll}
\hline Experiment No. & $\begin{array}{l}\text { First checks } \\
\text { after: (h) }\end{array}$ & $\begin{array}{l}\text { Visible collapse } \\
\text { After: (h) }\end{array}$ \\
\hline 1 & 35 & 72 \\
2 & 58.5 & 68.5 \\
3 & 56 & 77 \\
4 & 71 & 71 \\
\hline
\end{tabular}

Nevertheless, the comparison between these results must take into account the differences in the processes and in the drying rate in the different experiments.

\subsection{Future work}

More research will be performed trying to take into account all the factors that may influence the quality of the final product regarding both surface checking and cell collapse. Multivariate statistical studies may be useful in the future. The development of the equipment and the method to replicate these drying schedules also needs more work, as processes with low temperatures and air velocities has shown to be troublesome. Furthermore, research on the implementation of pump-drying is currently being carried out, which shows a potential for energy savings as the fans are intermittently stopped during much of the drying time. 


\section{Conclusions}

The drying of Eucalyptus nitens has been shown to differ to some extent with regard to the appearance of checks and cell collapse-related features depending on the temperature, but the drying rate does not seem to be greatly affected by temperature. It can be concluded from these studies that Eucalyptus nitens should be dried at a low temperature and a low air velocity, as is done industrially in Chile, to avoid damage. Improving the efficiency of the drying process in terms of time and, thus, energy, does not seem likely as the process must be slow in order to avoid surface checking and cell collapse. The results do not suggest that high temperature drying would give higher drying rate, thus the increase in energy consumption would not be worth it.

\section{Acknowledgements}

The project Eu-Trä: Innovativ Svenska teknik för tillverkning av chilenska eukalyptus till sågade trävaror (DNo. 2017-01524) is financed by the Eureka program (Vinnova, Sweden's Innovation Agency) and is being carried out in collaboration with Alent Dynamic AB (Sweden) and TSST Energy LTDA (Chile).

\section{References}

[1] OECD - Organisation for Economic Cooperation and Development. Consensus Document on the Biology of Eucalyptus spp. Paris, 2014.

[2] Gysling, A. J.; Álvarez, V. C.;Soto, D. A.; Pardo, E. J.; Poblete, P. A.; Bañados, J. C. Chilean Statistical Yearbook of Forestry 2017. Statistical Bulletin $\mathrm{N}^{\circ} 159$. Metropolitan Office, Forestry Institute, Santiago, Chile, 2018.

[3] Blackburn, D. P. Improving Eucalyptus Nitens for Sawn-Board, Veneer and Paper Products. Doctoral thesis, University of Tasmania, 2012.

[4] Sharma, M.; Walker, J. C. F.; Chauhan, S. S. Eliminating Growth-Stresses in Eucalyptus: A Scoping Study with E. bosistoana and E. nitens. In Wood is Good; Springer, Singapore, 2007; pp 47-54.

[5] Kong, L.; Zhao, Z.; He, Z.; Yi, S. Development Of Schedule To Steaming Prior To Drying And Its Effects On Eucalyptus Grandis $\times$ E. Urophylla Wood. European Journal of Wood and Wood Products 2017, 76, 591-600.

[6] McKinley, R.; Shelbourne, C.; Low, C.; Penellum, B.; Kimberley, M. Wood properties of young Eucalyptus nitens, E. globulus, and E. maidenii in northland, New Zealand. New Zealand Journal of Forestry Science. 2002, 32(3), 334-356.

[7] Shelbourne, C., Nicholas, I., McKinley, R., Low, C., McConnochie, R., Lausberg, M. Wood density and internal checking of young Eucalyptus nitens in New Zealand as 
affected by site and height up the tree. New Zealand Journal of Forestry Science. 2002, 32(3), 357-385.

[8] Lausberg, M.; Gilchrist, K.; Skipwith, J. Wood properties of Eucalyptus nitens grown in New Zealand. New Zealand Journal of Forestry Science. 1995, 25(2), 147-163.

[9] Yang, L.; Liu, H. A Review of Eucalyptus Wood Collapse and its Control during Drying. BioResources. 2018, 13(1), 2171-2181.

[10] Wilkes, J.; Wilkins, A. Anatomy of collapse in eucalyptus species. IAWA Journal. 1987, 8(3), 291-295.

[11] Chauhan, S. S.; Walker, J. Relationships between longitudinal growth strain and some wood properties in eucalyptus nitens. Australian Forestry. 2004, 67(4), 254-260.

[12] Valenzuela, C.; Bustos, A.; Lasserre, J.; Gacitúa, E. Characterization nanomechanics of wood cell structure and anatomy in Eucalyptus nitens and its relation to the cracking cracking and fractures in round wood. Maderas: Ciencia y Tecnología. 2012, 14(3), 321- 337.

[13] McKenzie, H. M.; Turner, J. C. P.; Shelbourne, C. J. A. Processing young plantationgrown Eucalyptus nitens for solid-wood products. 1: Individual-tree variation in quality and recovery of appearance-grade lumber and veneer. New Zealand Journal of Forestry Science. 2003, 33(1), 62-78.

[14] Ilic, J. Shrinkage-related degrade and its association with some physical properties in Eucalyptus regnans F. muell. Wood Science and Technology.1999, 33(5), 425- 437.

[15] Hamilton, M. G.; Raymond, C. A.; Harwood, C. E.; Potts, B. M. Genetic variation in Eucalyptus nitens pulpwood and wood shrinkage traits. Tree Genetics Genomes. 2009, 5(2), 307-316.

[16] Kube, P. D.; Raymond, C. A. Breeding to minimize the effects of collapse in Eucalyptus nitens. CRC for Sustainable Production Forestry: Tasmania, Australia 2002.

[17] Wentzel-Vietheer, M.; Washusen, R.; Downes, G. M.; Harwood, C.; Ebdon, N.; Ozarska, B.; Baker, T. Prediction of non-recoverable collapse in Eucalyptus globulus from near infrared scanning of radial wood samples. European Journal of Wood and Wood Products. 2013, 71(6), 755-768. doi:10.1007/s00107-013-0735-y

[18] Ananías, R. A.; Sepúlveda-Villarroel, V.; Pérez-Peña, N.; Leandro-Zuñiga, L.; SalvoSepúlveda, L.; Salinas-Lira, C.; Cloutier, A.; Elustondo, D. M. Collapse of Eucalyptus nitens wood after drying depending on the radial location within the stem. Drying Technology. 2014, 32(14), 1699-1705. 